\title{
Economic Growth, Nation Building and Societal Wellbeing: Impact of R\&D and Industrial Revolutions
}

\author{
Mustafa Mohd Hanefah \\ Faculty of Economics and Muamalat \\ Universiti Sains Islam Malaysia (USIM) \\ Nilai, Malaysia \\ mustafa@usim.edu.my
}

\begin{abstract}
The fast development in science and technology has contributed to the advancement of knowledge in many disciplines. Mankind has gained new knowledge from new discoveries that have enhanced the wellbeing of the society, improved their lives with better health. Scientists have discovered many new things beginning from the second century and till now. These innovations and inventions have contributed a lot to societal wellbeing in generating better income and a healthy lifestyle for modern living. This paper compares past achievements of Muslim scientists and the state of the art of R\&D and STEM education in OIC countries. Scientific discoveries beginning the first industrial revolution o the current IR4.0 are compared and discussed. Recommendations are made based on the critical analysis of past achievements and future innovations
\end{abstract}

Keywords-Science and technology; research and development; Muslim scientists; education policy and societal wellbeing

\section{INTRODUCTION}

Science and technological developments over the past decades have contributed to the development of humankind in many areas, especially to improve the lives of mankind, better health, societal wellbeing, infrastructure facilities, easy and faster communications and many others. This has been possible due to the advancement of knowledge through research and development $(R \& D)$ activities undertaken by scientists from western and Arab worlds.

With new discoveries and knowledge gained, science is continually refined and expands our knowledge of the universe, and as it does, it leads to new questions and findings for future investigations. These future investigations lead to new findings, discoveries, innovations and new knowledge that lead to better quality of life and longevity.

The fast development of science over the centuries has brought immense discovery and advancement in the wellbeing and wealth generation of humankind. S\&T too has become the drivers of change to nation building and economic growth. Undeniably S\&T has given a comparative advantage for nations to gain knowledge and produce products that enabled them to conquer the world markets. It is interesting to see the great discoveries made by scientists over the past centuries. Table 1 gives a summary of the discoveries beginning from the second century till now.

While it is interesting to note that scientific discoveries in the west and east in the past have contributed to the development of nation growths in the west, this however is not the truth in other countries especially among Muslim countries. Table 1 gives a candid picture of the scientific achievements of the great scholars in the west and in the Middle East. Beginning from the second century many advancements were made by scientists.

What is interesting from table 1 is that discoveries by Muslim scientists have enabled modern scientists to further advance their research work and innovations. From the 7 th century to 15 th century, when there was no progress in the west or during the medieval age of Europe, Islamic scientists were making huge impact from their research and contributing knowledge to other scientists, researchers and to the wellbeing of the society. The west called this period or era as the dark ages, but actually it was the golden age of the Muslim world. The Muslim world prospered due to new discoveries and scientific achievements by the scientists in Baghdad, Iraq. The environment was very conducive for the advancement of S\&T. The ruler or caliph provided the necessary enablers for the advancement in S\&T and new discoveries.

However, after the 16th century when the Muslims were defeated in Cardoba - Al-Andalus, Muslims scholars did not make any advancement in new knowledge and discoveries. In fact, Arab and the Muslim world lost out to the western world in terms of knowledge and new discoveries. Historians and scholars agree that the downfall of Andalus as the main reason for the backwardness of new discoveries in the Arab and Muslim countries. Also the shift of political power and structure in these countries could also be the reason for lack of interest in the development of S\&T (Ahmed \& Albuarki, 2017). 
TABLE 1 GREAT DISCOVERIES IN SCIENCE

\begin{tabular}{|c|c|c|}
\hline $\begin{array}{l}\text { Period - } \\
\text { century }\end{array}$ & Scientist & Discovery \\
\hline $\begin{array}{c}{ }_{2}^{\text {nd }} \\
\text { century }\end{array}$ & Seleucus Selevcia & Tides are caused by moon \\
\hline $\begin{array}{c}{ }_{3}^{\text {rd }} \\
\text { century }\end{array}$ & Euclid & Geometry - The Elements \\
\hline $\begin{array}{l}{ }_{4}^{\text {th }} \\
\text { century }\end{array}$ & Theophrastus & $\begin{array}{l}\text { Mandragora that contains } \\
\text { atropine that cures } \\
\text { wounds, gout and } \\
\text { sleeplessness }\end{array}$ \\
\hline $\begin{array}{c}{ }_{7}^{\text {th }} \\
650-704 \\
702-765\end{array}$ & $\begin{array}{l}\text { Umayyad Prince } \\
\text { Khalid } \\
\text { Jaafar ibn Sadiq } \\
\text { Jabir ibn Hayyan }\end{array}$ & $\begin{array}{l}\text { Translates Egyptian } \\
\text { alchemical works into } \\
\text { Arabic } \\
\text { Critiques Aristotle and } \\
\text { suggests atomic theory } \\
\text { Discovers ethanol, acids, } \\
\text { rust proofing of metal \& } \\
\text { coloring of glass. }\end{array}$ \\
\hline${ }_{763-809}{ }^{\text {th }}$ & $\begin{array}{l}\text { Abbasid Caliph } \\
\text { Harun-al-Rashid } \\
\text { Al-Kindi and Al- } \\
\text { Razi and others } \\
\text { Al-Khwarizmi }\end{array}$ & $\begin{array}{l}\text { House of Wisdom (Baitul } \\
\text { Hikmah) in Baghdad } \\
\text { Recruits thinkers and } \\
\text { translators from India, } \\
\text { Persia and Syria. } \\
\text { First Arab-Muslim } \\
\text { hospital opens in } \\
\text { Baghdad. } \\
\text { First Arab psychiatric } \\
\text { hospitals established in } \\
\text { Baghdada and Fez, } \\
\text { Morocco. } \\
\text { Develop laboratory tools } \\
\text { like scissors, tongs, } \\
\text { cauldrons, bellows, lead, } \\
\text { iron and copper } \\
\text { compounds. } \\
\text { Introduces the Hindu- } \\
\text { Arabic numerals - the } \\
\text { zero, negative numbers } \\
\text { and invents algebra, } \\
\text { calendars and star tables. }\end{array}$ \\
\hline $\begin{array}{c}9^{\text {th }} \\
800-873\end{array}$ & $\begin{array}{l}\text { Al-Kindi } \\
\text { Banu Musa } \\
\text { brothers } \\
\text { AL- Mamun } \\
\text { Abbas ibn Firnas }\end{array}$ & $\begin{array}{l}\text { Theory of transmutation of } \\
\text { metals, creates } \\
\text { cryptography, metallutgy } \\
\text { and cosmetics. } \\
\text { Invents the first on-off } \\
\text { switch, float valve, gas } \\
\text { mask, self-trimming lamp } \\
\text { and other modern devices. } \\
\text { First Medical school }\end{array}$ \\
\hline
\end{tabular}

\begin{tabular}{|c|c|c|}
\hline $850-929$ & $\begin{array}{l}\text { Thabit ibn Qurra } \\
\text { Al-Battani }\end{array}$ & $\begin{array}{l}\text { founded in Banghdad. } \\
\text { Invents first manned glider } \\
\text { flight outside Cordoba - } \\
\text { Al-Andalus. } \\
\text { Develops higher Arab } \\
\text { geometry and number } \\
\text { theory. } \\
\text { Develops higher } \\
\text { astronomical and } \\
\text { mathematical concepts } \\
\text { and is quoted } 23 \text { times by } \\
\text { Copernicus } 600 \text { years } \\
\text { later. }\end{array}$ \\
\hline 936-1013 & $\begin{array}{l}\text { Muhammad ibn } \\
\text { Zakariya al-Razi } \\
\text { Al-Zahrawi }\end{array}$ & $\begin{array}{l}\text { Measles, smallpox, } \\
\text { kerosene and distilled } \\
\text { petroleum. } \\
\text { Father of modern surgery } \\
\text { - revolutionizes medical } \\
\text { treatment in Cordoba - } \\
\text { Al-Andalus. }\end{array}$ \\
\hline & Ibn Sahl & $\begin{array}{l}\text { Accurately describing } \\
\text { optics }\end{array}$ \\
\hline $981-1037$ & $\begin{array}{l}\text { Ibn Al-Haytham } \\
\text { Ibn Sina }\end{array}$ & $\begin{array}{l}\text { Book of Optics. Father of } \\
\text { modern optics. } \\
\text { Prince of medicine- wrote } \\
\text { the world's most } \\
\text { comprehensive medical } \\
\text { encyclopedia - the Canon } \\
\text { of Medicine. }\end{array}$ \\
\hline $12^{\text {th }}$ & $\begin{array}{l}\text { Al-Khazini } \\
\text { Ibn Bajjah }\end{array}$ & $\begin{array}{l}\text { Variation of gravitation } \\
\text { Discovery of reaction - } \\
\text { precursor to Newton's } \\
\text { third law of motion }\end{array}$ \\
\hline $\begin{array}{c}1125- \\
1166\end{array}$ & $\begin{array}{l}\text { Averroes } \\
\text { Ibn Zuhr } \\
\text { Mohammed Al- } \\
\text { Idrisi }\end{array}$ & $\begin{array}{l}\text { Relationship between } \\
\text { force, work and kinetic } \\
\text { energy. } \\
\text { Father of tracheotomy - } \\
\text { further advances Arab } \\
\text { medical discovery in Al- } \\
\text { Andalus. } \\
\text { Created world maps - also } \\
\text { used by European } \\
\text { explorers. }\end{array}$ \\
\hline 1206 & Al-Jazari & $\begin{array}{l}\text { Circulatory system- } \\
\text { discovers the anatomy of } \\
\text { heart-lung blood } \\
\text { circulation in Cairo, } \\
\text { Egypt. } \\
\text { Published Book of } \\
\text { Knowledge of ingenious } \\
\text { mechanical devices. } \\
\text { Invents the first torpedo. }\end{array}$ \\
\hline
\end{tabular}




\begin{tabular}{|c|c|c|}
\hline & $\begin{array}{l}\text { William of Saint } \\
\text { Cloud }\end{array}$ & $\begin{array}{l}\text { Camera obscura to view } \\
\text { solar eclipses. }\end{array}$ \\
\hline \multirow[t]{2}{*}{$14^{\text {th }}$} & Jean Buridan & Theory of impetus \\
\hline & Nicole Oresme & $\begin{array}{l}\text { Curvature of light through } \\
\text { atmospheric refraction. }\end{array}$ \\
\hline $\begin{array}{l}1304- \\
1369\end{array}$ & Ibn Batuta & $\begin{array}{l}\text { Travels the world covering } \\
75,000 \text { miles. }\end{array}$ \\
\hline 1377 & Ibn Khaldun & $\begin{array}{l}\text { Father of modern } \\
\text { historiography and social } \\
\text { science published } \\
\text { Prolegomenon. }\end{array}$ \\
\hline 15th & $\begin{array}{l}\text { Chinese Muslim } \\
\text { Admiral Zheng } \\
\text { He }\end{array}$ & $\begin{array}{l}\text { Explorer of the Indian } \\
\text { Ocean. }\end{array}$ \\
\hline \multirow[t]{2}{*}{${ }_{16}$ th } & $\begin{array}{l}\text { Nicolaus } \\
\text { Copernicus }\end{array}$ & Heliocentric model \\
\hline & Vesalius & $\begin{array}{l}\text { Pioneering work in human } \\
\text { anatomy }\end{array}$ \\
\hline \multirow[t]{5}{*}{$17^{\text {th }}$} & John Napier & $\begin{array}{l}\text { Use of logarithms for } \\
\text { calculation }\end{array}$ \\
\hline & William Harvey & Blood circulation \\
\hline & Galileo Galilie & $\begin{array}{l}\text { Telescopic observations, } \\
\text { laws of falling body }\end{array}$ \\
\hline & Robert Boyle & Boyle's law of ideal gas \\
\hline & Isaac Newton & Laws of motion \\
\hline \multirow[t]{4}{*}{$18^{\text {th }}$} & $\begin{array}{l}\text { Benjamin } \\
\text { Franklin } \\
\end{array}$ & Lightning is electrical \\
\hline & Thomas Bayes & $\begin{array}{l}\text { Bayes Theorem } \\
\text { Bayesian probability }\end{array}$ \\
\hline & Alessandro Volta & battery \\
\hline & William Herschel & Infrared Radiation \\
\hline \multirow[t]{7}{*}{$19^{\text {th }}$} & John Dalton & Atomic theory \\
\hline & Michael Faraday & Electromagnetic induction \\
\hline & Louis Pasteur & Germ theory \\
\hline & Friedrich Renitzer & Liquid crystals \\
\hline & $\begin{array}{l}\text { Wilhelm Conrad } \\
\text { Rontgen }\end{array}$ & $\mathrm{x}$-rays \\
\hline & Henri Becquerel & Radioactivity \\
\hline & Marie Curie & Polonium \& radium \\
\hline \multirow[t]{5}{*}{$20^{\text {th }}$} & Albert Einstein & $\begin{array}{l}\text { Theory of special and } \\
\text { general relativity }\end{array}$ \\
\hline & Edwin Hubble & Milky Way \\
\hline & $\begin{array}{l}\text { Alexander } \\
\text { Fleming } \\
\end{array}$ & Penicillin \\
\hline & Jonas Salk & Polio vaccine \\
\hline & & $\begin{array}{l}\text { Internet } \\
\text { Islamic Finance }\end{array}$ \\
\hline
\end{tabular}

Source: Wikipedia and Arab Science (Qatar Foundation)

Science has contributed to many new developments that have led to the wellbeing of humankind, and wealth creation. However, the societal wellbeing and wealth have been confined to the developed countries and now in developing countries like China are beginning to adopt R\&D to improve the inventions. Wealth created from science is only used to create more wealth in the developed countries and very little in under developed countries such as in Africa, East Europe and South America.

This trend was not the case during the Abassid's golden era of knowledge and science. Knowledge was freely available and shared. During this golden era, Muslim scientists gave the new world with new innovations and inventions in almost all disciplines, covering medicine, physics, chemistry, astronomy, philosophy, mathematics, social science and others.

It is acknowledged that the dark ages of western civilization was the golden ear of scientific discoveries in the Muslim world. These Muslim scholars and scientists gained knowledge through Al-Quran, Hadiths of the prophet Muhammad saw and also from other civilizations especially the Greeks, Persians and the Indians.

Scientific discoveries by the Muslim scientists have made impact on other scientists and societies in general. The industrial revolutions in Europe and in the USA took place after the golden era of Islamic scientific revolutions beginning 18 th century. The next section discusses the impact of the industrial revolutions on humankind and economic development in the world.

\section{IndUSTRIAL REVOLUTIONS, ECONOMIC GROWTH AND DEVELOPMENT}

Industrial revolutions have an impact on economic growth and societal wellbeing. There are four industrial revolutions so far. Each period has its own discoveries that had impact on almost all things. The following section briefly describes the industrial revolutions.

\section{A. The First Industrial Revolution: 1765-1869}

The first industrial revolution took place at the end of the 18 th century to the beginning of the 19th century. Before this revolution, the world was almost dependent on agriculture sector rather than the industrial sector. Industrialization replaced the agricultural sector as primary source of revenue for western countries. Mechanization was the order of the day. Steam engine and railways modernized the transportation system with a bigger demand for coal. New cities were built to meet the demands of migration.

\section{B. The Second Industrial Revolution: 1870- 1968}

In this era, new sources of energy: electricity, gas and oil paved the way for new inventions. Combustion engines replaced steam engines as driver of economic growth, and new sources of energy like electricity, gas and oil paved the way for new inventions and discoveries in S\&T.

In this era, communication and transportation were made easier and faster with the invention of the telephone, telegraph, cars and planes. Agriculture was also modernized with new machines and tools. 


\section{The Third Industrial Revolution: 1969 - 2015}

As in the other two earlier revolutions, new energy in the form of nuclear led to many new inventions and industry. The electronics and microprocessor industries flourished during this era. Telecommunication, computer programming, space and biotechnology industries also saw a tremendous rise during this period. Automation and robots were also key features in this era.

\section{The Fourth Industrial Revolution: 2016 - present}

We are now in the fourth industrial revolution. This is actually the continuation of the third industrial revolution. The fourth industrial revolution or 4.0IR is also known as the digital revolution.

This fourth revolution with exponential expansion is made possible by merging technology that crosses many disciplines like the physical, digital and biological spheres to completely disrupt the industries all over the world. Disruptive economy is the word used to describe the major change in the way business is done in this IR4.0 era or otherwise also known as Digital era. This digital era has already seen the growth of Internet and its impact on digital economy or e-commerce.

Mind-blowing inventions are capturing the markets at a much faster rate than before. New inventions include driverless car, Internet of Things (IoT), artificial intelligence (AI) and $3 \mathrm{D}$ printers. 3D printers are now used to print many new products. The latest being human parts. This is now known as the bioink technology or bioprinting. This latest invention by a Swedish company, known as CellInk anticipate that bioprinting could be used to create functioning human organs for implantations. Summary of the different eras is in table 2 .

TABLE 2 INDUSTRIAL REVOLUTION

\begin{tabular}{|c|l|l|}
\hline IR & Period & Inventions \\
\hline$I^{\text {st }} \mathbf{I R}$ & $\begin{array}{l}\text { End of 18th to } \\
\text { 19th centuries in } \\
\text { Europe and } \\
\text { America. }\end{array}$ & $\begin{array}{l}\text { It was a period when } \\
\text { mostly agrarian, rural } \\
\text { societies became } \\
\text { industrial and urban. } \\
\text { The iron and textile } \\
\text { industries, along with } \\
\text { the development of the } \\
\text { steam engine, played } \\
\text { central roles in the } \\
\text { Industrial Revolution. }\end{array}$ \\
\hline $2^{\text {nd }} \mathbf{I R}$ & $\begin{array}{l}1870 \text { and } 1914, \\
\text { just before World } \\
\text { War I }\end{array}$ & $\begin{array}{l}\text { It was a period of } \\
\text { growth for pre-existing } \\
\text { industries and } \\
\text { expansion of new ones, } \\
\text { such as steel, oil and } \\
\text { electricity, and used } \\
\text { electric power to create } \\
\text { mass production. Major } \\
\text { technological advances } \\
\text { during this period } \\
\text { included the telephone, }\end{array}$ \\
\hline
\end{tabular}

\begin{tabular}{|c|l|l|}
\hline & & $\begin{array}{l}\text { light bulb, phonograph } \\
\text { and the internal } \\
\text { combustion engine. }\end{array}$ \\
\hline $3^{\text {rd }}$ IR & $\begin{array}{l}\text { From 1980s } \\
\text { onwards }\end{array}$ & $\begin{array}{l}\text { Advancements during } \\
\text { the Third Industrial } \\
\text { Revolution include the } \\
\text { personal computer, the } \\
\text { internet, and } \\
\text { information and } \\
\text { communications } \\
\text { technology (ICT). }\end{array}$ \\
\hline $4^{\text {th } I R}$ & $2016-$ & $\begin{array}{l}\text { Digital Revolution } \\
\text { The Fourth Industrial } \\
\text { Revolution is marked } \\
\text { by emerging technology } \\
\text { breakthroughs in a } \\
\text { number of fields, } \\
\text { including robotics, } \\
\text { artificial intelligence, } \\
\text { nanotechnology, } \\
\text { quantum computing, } \\
\text { biotechnology, The } \\
\text { Internet of Things, 3D } \\
\text { printing and } \\
\text { autonomous vehicles. }\end{array}$ \\
\hline
\end{tabular}

\section{RESEARCH AND DEVELOPMENT EXPENDITURE}

New knowledge gave the birth of new revolutions. They then had a tremendous impact on societal wellbeing and nations economic growth and developments. These revolutions too had an impact on social, economy, politics and education. All these changes are brought about by the amount of research and development a nation invests in. Table 2 below show the amount of R\&D spending by a number of countries in the world.

All the top countries in the list are from the west. Very few Muslim countries are investing in R\&D. South Korea is spending about $4.3 \%$ of its GDP in R\&D activities. Japan is also spending about $3.5 \%$ of its GDP on R\&D. It is little wonder that these countries are in the lead. Muslim countries except Malaysia and Turkey are spending less than 1\% on the average on $\mathrm{R} \& \mathrm{D}$. This is too little for economic progress and wealth generation. Only if R\&D expenditure is increased can Muslim countries compete with other developed countries. Most of the OIC countries are spending less than $0.5 \%$ of the GDP on R\&D. This is not enough for advancing S\&T agenda for the Ummah.

\section{A. Government Expenditure on Education}

Even government expenditure on education is gradually going down. OIC countries are less committed to education. As shown in figure 1, OIC countries expenditure on education was high only in 2003 (4.43\% of the GDP), but has dropped to $3.70 \%$ of the GDP in 2012. 
OIC countries should give priority to education. Education is the key to the success of $\mathrm{R} \& \mathrm{D}$ development. Also governments should give more attention to Science, Technology, Engineering and Mathematics (STEM) education in order to future proof the education system against new challenges.

Figure 1: Overall Govt Expenditure on Education

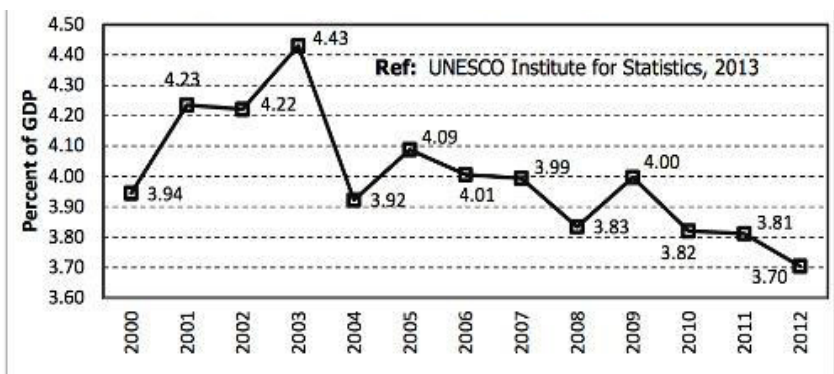

Source: Comstech, 2016

\section{B. OIC Enrolments in Technical and Vocational Education}

Figure 2 below show OIC countries enrolments in technical and vocational education. It shows an upward trend beginning 2008. This is good news for technical and vocational education in OIC countries. Nevertheless, after reaching a peak in 2011, enrolment in technical and vocational education in OIC countries is gradually slowing down. What is much need is more spending in STEM education and R\&D activities among OIC countries.

Figure 2: OIC Enrolments in Teachnical / Vocational Education

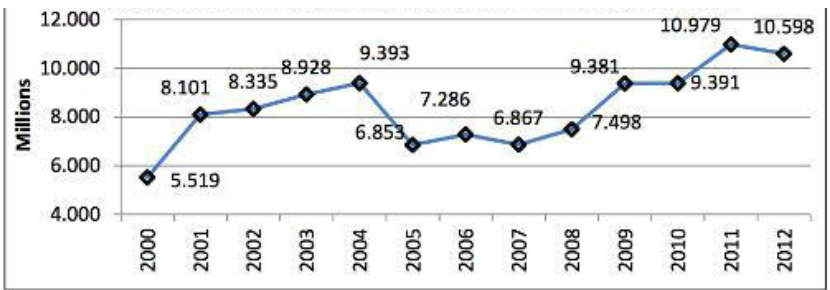

Ref: SESRIC; Education And Scientific Development in OIC Countries, 2014 UNESCO; World Bank WDI, World Bank Education Statistics. * Or latest year

Source: Comstech, 2016

\section{C. $R \& D$ Expenditure as a percentage of GDP Units}

Gross domestic expenditure on R\&D (GERD) as a percentage of GDP among OIC countries is shown in figures 3 and 4 . The highest was in $2010(0.42 \%)$ and the lowest was in $2000(0.28 \%)$. Most of the developed nations like the USA, Germany, France, Japan, South Korea spend more than $2 \%$ of the GDP on R\&D. In order to succeed, OIC countries must increase their R\&D expenditure to at least to $0.5 \%$ by 2020 and $1 \%$ by 2025 . Only Malaysia and Tunisia are spending more than $1 \%$ of their GDP on R\&D. Turkey is also increasing its $R \& D$ expenditure.
Figure 3. Gross Domestic Expenditure on R\&D as a Percentage of GDP of OIC Member States

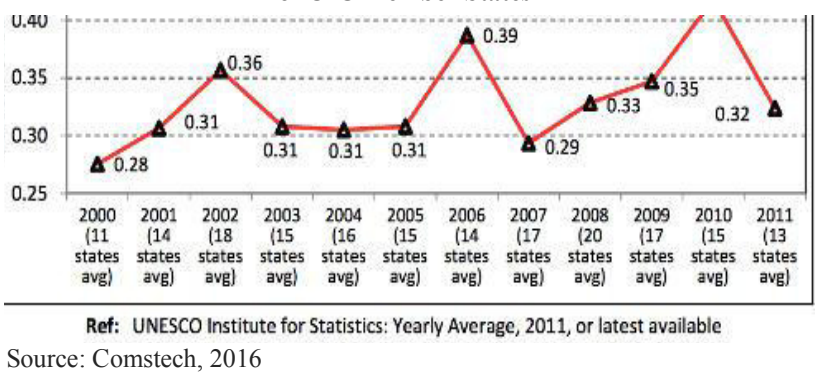

Figure 4 : Gross Domestic Expenditure on R\&D, as \% of GDP of 31 OIC Countries (2011 or latest available years)

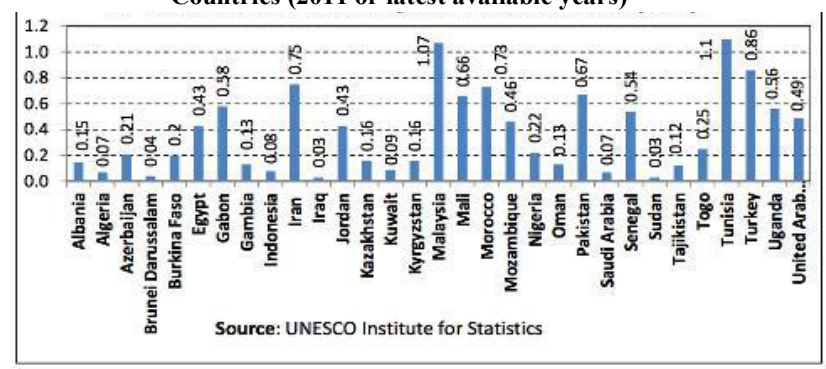

Source: Comstech, 2016

\section{CONCLUSION}

In this paper a number of issues regarding science and technology, research and development for economic growth, societal wellbeing and nation building, especially among OIC countries are discussed. A brief history of the discoveries made during the 2 nd to 21 st century gives us the impact of such discoveries to mankind and economic development among the countries. Contributions by Muslim scientists are also highlighted. The golden era of Islamic science is also the dark ages of the western world. But this changed when the western civilization embarked on a scientific road that led to many industrial revolutions and tools for modern living. Western scientists took many of the findings from the Muslim scholars and improved them.

The following are recommendations for a successful R\&D development and implementation in OIC countries:

- A national Science and Technology policy must be in place.

- Implementation and monitoring of S\&T policy is important.

- An integrated school education system should be introduced. Integration of Naqli and Aqli knowledge should be enforced.

- $\quad$ Public and private partnership is important for the success of S\&T policy.

- Universities and the industry must undertake $\mathrm{R} \& \mathrm{D}$ activities together.

- Need to inculcate a research and innovation culture among the school and university students, academics and society at large.

- $\quad \mathrm{R} \& D$ expenditure should be increased.

- $\quad$ Establish innovation centers like House of Wisdom. 
REFERENCES

[1] A. J. Ahmed, D., "Review Of The Challenges Of Scientific Research In The Arab World And Its Influence On Inspiration Driven Economy," Int. J. Inspir. Resil. Econ., vol. 1, no. 1, pp. 28-34.

[2] Science And The Ummah: Nurturing The Thinking Mind: Sessions Of

The 30th Executive Committee And 15th General Assembly Of. Islamabad, Pakistan: COMSTECH.

[3] W. Bank, "Research And Development Expenditure (\% of GDP)." World Bank, 2016.

[4] W. Bank, "Research And Development Expenditure (\% Of GDP)." data.worldbank.org., 2017. 
